Shaw, C. \& Clarke, P. H. (1955). J. gen. Microbiol. 13, 155-161.

\title{
Biochemical Classification of Proteus and Providence Gultures
}

\author{
By CONSTANCE SHAW AND PATRICIA H. CLARKE* \\ National Collection of Type Cultures, Colindale Avenue, London, N.W. 9
}

SUMMARY: Biochemical reactions of 153 Providence (29911 type) and 63 Proteus cultures were examined. Providence cultures are included in the genus Proteus, as their cultural characters are similar; this relationship is strengthened by the production of L-amino acid oxidase and glutamic acid decarboxylase by both. Proteus inconstans Ornstein nov.comb. is the name proposed for Providence cultures.

The family Enterobacteriaceae includes many groups which have a position intermediate between the established genera; of these the paracolon 29911 type (Stuart, Wheeler, Rustigian \& Zimmerman, 1943) or Providence group (Brooke, 1951; Kauffmann, 1951) were found by biochemical tests to be related to the genus Proteus (Ewing, Tanner \& Dennard, 1954). We have investigated the distribution of several biochemical characters among the Enterobacteriaceae, in particular the ability to metabolize potassium gluconate, sodium malonate, and also to attack amino acids by oxidative deamination or decarboxylation. The results we have obtained confirm the close relation of the Providence cultures to the species of the genus Proteus.

\section{METHODS}

Strains. The cultures of Proteus spp. and other genera examined were those maintained at the National Collection of Type Cultures. The strains examined included: Bacillus inconstans (Ornstein, 1921), an intestinal organism described and deposited by Braun in 1926; the three original strains of the Wakefield bacillus (Berger, 1945); B 81 and B 105 of Sachs's mannitol-negative dysentery organisms (Sachs, 1943); Stuart's paracolon 29911 type. Later, we obtained 120 Providence cultures from Dr W. H. Ewing (these are listed as Providence (2) in Table 2), and freshly isolated strains from faeces collected by different laboratories of the Public Health Laboratory Service during investigations of diarrhoea.

\section{Biochemical tests}

Gluconate test. The medium was a modification of that used by Haynes (1951) for pseudomonads. It consisted of: Evans's peptone, 1.5 g.; Yeastrel, 1.0 g.; $\mathrm{K}_{2} \mathrm{HPO}_{4}, 1.0 \mathrm{~g}$; potassium gluconate, $40.0 \mathrm{~g}$; d distilled water, $1000 \mathrm{ml}$; adjusted to $\mathrm{pH} 7 \cdot 0$; sterilized $10 \mathrm{lb} . / \mathrm{sq} . \mathrm{in}$. for $10 \mathrm{~min}$. After incubation of the culture for $48 \mathrm{hr}$. at $37^{\circ}, 1.0 \mathrm{ml}$. of Benedict's qualitative reagent for reducing sugars was added and the tubes placed in boiling water for $10 \mathrm{~min}$.

* Present address: Department of Biochemistry, University College, London, W.C. 1. 
A positive test showed a yellowish brown precipitate of cuprous oxide and there was a characteristic smell of decaying cabbage.

Phenylalanine and malonate tests. Leifson's (1933) sodium malonate and Henriksen's (1950) phenylalanine tests were combined by adding phenylalanine to Leifson's medium: the combined medium was supplemented with $0 \cdot 1 \%$ Yeastrel to increase growth. The medium was as follows: $\left(\mathrm{NH}_{4}\right)_{2} \mathrm{SO}_{4}$, $2 \cdot 0$ g.; $\mathrm{K}_{2} \mathrm{HPO}_{4}, 0 \cdot 6$ g. ; $\mathrm{KH}_{2} \mathrm{PO}_{4}, 0 \cdot 4$ g.; $\mathrm{NaCl}, 2 \cdot 0$ g.; sodium malonate, $3 \cdot 0$ g.; DL-phenylalanine, 2.0 g.; Yeastrel, $1.0 \mathrm{~g}$; $0.5 \%$ (w/v) ethanolic bromthymol blue, $5 \mathrm{ml}$; d distilled water, $1000 \mathrm{ml}$.; sterilized $10 \mathrm{lb} . / \mathrm{sq}$.in. for $10 \mathrm{~min}$. Cultures were incubated overnight at $37^{\circ}$ and organisms using malonate produced an alkaline reaction. When a few drops of $0 \cdot 1 \mathrm{~N}-\mathrm{HCl}$ and a few drops of $0.5 \mathrm{M}$-ferric chloride were added to the tubes, a deep green colour indicated the production of phenylpyruvic acid from phenylalanine (Henriksen \& Closs, 1938).

Indole and $\mathbf{H}_{2} \mathrm{~S}$ production were shown, respectively, by oxalic acid papers (Holman \& Gonzales, 1923) and lead acetate papers inserted above cultures in Lemco broth $+\mathbf{0} .01 \%$ cysteine incubated at $37^{\circ}$ for up to 7 days (Clarke, 1953).

Gelatin liquefaction was observed in nutrient gelatin stab cultures incubated for 30 days at $22^{\circ}$.

Hydrolysis of urea. Stuart, van Stratum \& Rustigian's (1945) highly buffered medium and also Christensen's (1946) weakly buffered nutrient urea agar were used. The tubes incubated at $37^{\circ}$ were read daily for 7 days.

Methyl-red test (MR). Cultures were grown in glucose phosphate peptone (Evans) medium and incubated for 5 days at $30^{\circ}$.

Voges-Proskauer test (vP). Three media, each containing Evans's peptone, were used. Glucose phosphate peptone medium; glucose peptone medium with $\mathrm{NaCl}$ but without phosphate (Smith, Gordon \& Clark, 1946); and glucose peptone medium without salt and phosphate (Abd-el-Malek \& Gibson, 1948). Cultures were incubated at $30^{\circ}$ for 5 days and tested for the presence of acetoin by Batty-Smith's (1941) modification of Barritt's (1936) $\alpha$-naphthol method.

Use of citrate as sole source of carbon. All tests were made by needle inoculation from a liquid culture. Koser's citrate medium (1923) was incubated for 7 days at $30^{\circ}$. All tubes showing turbidity were regarded as positive when confirmed by needle reinoculation into citrate.

Fermentation tests. Medium consisted of peptone water + bromcresol purple $+1 \%(\mathrm{w} / \mathrm{v})$ of 'sugar' and final readings made after incubation of cultures for 14 days at $37^{\circ}$. The 'sugars', tested were glucose, arabinose, xylose, rhamnose, lactose, sucrose, maltose, trehalose, glycerol, mannitol, dulcitol, sorbitol, inositol, adonitol and salicin.

\section{Microtests}

In most cases tests were carried out simultaneously on growing cultures and as microtests with washed suspensions (Clarke \& Cowan, 1952). Heavy suspensions were made from cultures grown overnight on Lemco agar at $37^{\circ}$. The microtests were carried out as follows: 
Phenylalanine. Two drops suspension, 2 drops $0.03 \mathrm{M}-$ phenylalanine, 2 drops $0.025 \mathrm{M}$-phosphate buffer, $\mathrm{pH} 6.8$. Incubated in a water-bath and after $1 \mathrm{hr}$. at $37^{\circ}$ tested by adding 2 drops $0 \cdot 5 \mathrm{M}-\mathrm{FeCl}_{3}$. Other amino acids were also used as substrates.

Malonate. Two drops suspension, 2 drops $0.03 \mathrm{~m}$-sodium malonate, 2 drops 0.025 M-phosphate buffer, pH $6 \cdot 0+$ phenol red as indicator. Results were read up to $\mathbf{2 4} \mathrm{hr}$. at $37^{\circ}$ and positive tests showed an alkaline reaction.

Decarboxylases. Two drops suspension, 2 drops $0.03 \mathrm{~m}$ solution amino acid adjusted to $\mathrm{pH} 5 \cdot 0,2$ drops $0 \cdot 0125 \mathrm{M}$-phthalate buffer, $\mathrm{pH} 5 \cdot \mathbf{0}+$ bromeresol purple. At this $\mathrm{pH}$ value $\mathrm{CO}_{2}$ is liberated so that the reaction mixture will show an indicator colour change when decarboxylation has taken place. Readings were taken at 2,4 and $24 \mathrm{hr}$. at $37^{\circ}$. Toluene was added in later tests. Each set of tests included a suspension control without amino acid; when this suspension was alkaline buffer was added to all tubes until a yellow colour was given by the control.

\section{RESULTS}

Table 1 summarizes the results of the tests made on the Proteus spp. and the Providence strains. Included among the Providence strains are Sachs's B 81 and B 105 and the Wakefield bacillus, which Stuart, Wheeler \& McGann (1946) showed to be members of the Providence group. NCTC 2481, Bacillus inconstans Ornstein, in our routine examination was found to have the biochemical characters of the Providence group. Dr W. H. Ewing confirmed this and has also shown that serologically the strain belongs to Providence 0 group 9.

Motile Providence strains, like Proteus spp., have a tendency to spread on agar. Therefore very dry plates were used to obtain single colonies. The cells were found to be peritrichously flagellate, though the flagella were few in number as compared with typical Proteus spp.

All strains of Proteus spp. and all but two of the Providence group produced phenylpyruvic acid by oxidative deamination of phenylalanine. The two negative cultures were positive by the micromethod, but had lower than average activity. There was no clear-cut division between any of the Proteus spp. and the Providence group when histidine was used as substrate (Singer, 1953). Stumpf \& Green (1944) found that freshly prepared suspensions of $P$. vulgaris could oxidatively deaminate nearly all the naturally occurring amino acids, and manometric studies on the Providence cultures show that there is considerable variation in the relative rates of oxidation of phenylalanine and histidine by different strains. The phenylalanine microtest was particularly sensitive; after $15 \mathrm{~min}$. incubation Proteus spp. and Providence cultures produced a deep green colour on the addition of ferric chloride. Other species of enterobacteria were negative (Table 2), but after $24 \mathrm{hr}$. incubation weak reactions were occasionally obtained with strains of Klebsiella aerogenes, Escherichia coli and some paracolons, so that the enzyme is not completely absent from these species.

Gluconate oxidation, originally used by Haynes to distinguish the pseudo- 
monads, is a useful test for klebsiellas. Providence and Proteus rettgeri strains do not oxidize gluconate, but a few strains of the other Proteus spp. give positive results in this test. The malonate test is invariably negative with Proteus and Providence cultures.

Table 1. Cultural characters of Proteus and Providence strains

\begin{tabular}{|c|c|c|c|c|c|c|c|c|c|c|}
\hline \multirow[b]{2}{*}{ Biochemical tests } & \multicolumn{2}{|c|}{ P. mirabilis } & \multicolumn{2}{|c|}{ P. morganii } & \multicolumn{2}{|c|}{ P. rettgeri } & \multicolumn{2}{|c|}{ P. vulgaris } & \multicolumn{2}{|c|}{$\begin{array}{l}\text { Providence } \\
\text { strains }\end{array}$} \\
\hline & + & - & + & - & + & - & + & - & + & - \\
\hline Motility & 22 & 1 & 22 & $\mathbf{2}$ & 8 & 1 & 2 & $\mathbf{5}$ & 144 & 9 \\
\hline Gluconate test & 13 & 10 & 1 & 23 & $\mathbf{0}$ & $\mathbf{9}$ & 0 & 7 & o & 153 \\
\hline Malonate test & $\mathbf{0}$ & 23 & 0 & 24 & 0 & 9 & 0 & 7 & 0 & 153 \\
\hline $\begin{array}{l}\text { Phenylalanine deami- } \\
\text { nation }\end{array}$ & 23 & 0 & 24 & 0 & 9 & $\mathbf{0}$ & 7 & 0 & 151 & $\mathbf{2}$ \\
\hline Indole & 0 & 23 & 24 & $\mathbf{0}$ & 8 & 1 & 7 & 0 & 151 & 2 \\
\hline $\mathrm{H}_{2} \mathrm{~S}$ produced & 22 & 1 & 24 & $\mathbf{0}$ & 9 & 0 & 7 & 0 & 153 & 0 \\
\hline$M R$ & 8 & 15 & 8 & 16 & 7 & 2 & 5 & 2 & 101 & $\mathbf{5 2}$ \\
\hline VP & 17 & 6 & $\mathbf{0}$ & 24 & 0 & 9 & 1 & 6 & 1 & 152 \\
\hline Gelatin liquefied & 18 & 5 & 0 & 24 & 0 & 9 & 4 & 3 & 0 & 153 \\
\hline Urea hydrolysed & 23 & $\mathbf{0}$ & 24 & $\mathbf{0}$ & 9 & 0 & 7 & $\mathbf{0}$ & 11 & 142 \\
\hline Citrate utilized & 6 & 17 & 1 & 23 & 8 & 1 & 4 & 3 & 96 & 57 \\
\hline Acid from & & & & & & & & & & \\
\hline Glucose & 23 & 0 & 24 & 0 & 9 & 0 & 7 & 0 & 153 & 0 \\
\hline Arabinose & 1 & 22 & $\mathbf{0}$ & 24 & 3 & 6 & 0 & 7 & 5 & 148 \\
\hline Xylose & 23 & 0 & 5 & 19 & 0 & 9 & 6 & 1 & 17 & 136 \\
\hline Rhamnose & 0 & 23 & $\mathbf{0}$ & 24 & 7 & 2 & 0 & 7 & 5 & 148 \\
\hline Lactose & 0 & 23 & 0 & 24 & 0 & 9 & 0 & 7 & 2 & 151 \\
\hline Sucrose & 19 & 4 & 1 & 23 & 9 & $\mathbf{0}$ & 7 & $\mathbf{0}$ & 146 & 7 \\
\hline Maltose & 1 & 22 & 0 & 24 & 0 & 9 & 7 & 0 & 9 & 144 \\
\hline Trehalose & 23 & 0 & $\mathbf{3}$ & 21 & 0 & 9 & 5 & 2 & 32 & 121 \\
\hline Glycerol & 22 & 1 & 20 & 4 & 8 & 1 & 7 & 0 & 80 & 73 \\
\hline Mannitol & 0 & 23 & 0 & 24 & 9 & $\mathbf{0}$ & 0 & 7 & 17 & 136 \\
\hline Dulcitol & 0 & 23 & $\mathbf{0}$ & 24 & 0 & 9 & 0 & 7 & $\mathbf{3}$ & 150 \\
\hline Sorbitol & 0 & 23 & 0 & 24 & 0 & 9 & 0 & 7 & 12 & 141 \\
\hline Inositol & $\mathbf{0}$ & 23 & 0 & 24 & 8 & 1 & $\mathbf{0}$ & 7 & 32 & 121 \\
\hline Adonitol & 0 & 23 & 0 & 24 & 9 & 0 & 0 & 7 & 110 & 43 \\
\hline Salicin & 4 & 19 & 0 & 24 & 5 & 4 & 5 & 2 & 9 & 144 \\
\hline
\end{tabular}

Table 2. Microtests for Proteus and Providence strains

\begin{tabular}{|c|c|c|c|c|c|}
\hline \multirow[b]{4}{*}{ P. vulgaris } & & \multicolumn{3}{|c|}{ Amino acid decarboxylase } & \multirow{2}{*}{$\begin{array}{c}\text { Deamine } \\
\text { Phenylala }\end{array}$} \\
\hline & \multirow{2}{*}{$\begin{array}{l}\text { No. } \\
\text { tested }\end{array}$} & Arginine & Lysine & Histidine & \\
\hline & & \multicolumn{4}{|c|}{ No. positive } \\
\hline & 6 & $\mathbf{0}$ & $\mathbf{0}$ & $\mathbf{0}$ & 6 \\
\hline P. mirabilis & 22 & $\mathbf{0}$ & $\mathbf{0}$ & $\mathbf{0}$ & 22 \\
\hline P. morganii & 23 & $\mathbf{0}$ & $\mathbf{0}$ & $\mathbf{0}$ & 23 \\
\hline P. rettgeri & 9 & 0 & $\mathbf{0}$ & $\mathbf{0}$ & 9 \\
\hline Providence (1) & 11 & 0 & $\mathbf{0}$ & 0 & 11 \\
\hline (2) & $47 *$ & $1+$ & 0 & $2 \dagger$ & 47 \\
\hline Other entero- & 75 & 65 & 42 & 10 & $\mathbf{0}$ \\
\hline
\end{tabular}

* Toluene added to the buffer in these tests (see text).

$\dagger$ Weak reactions. 
The decarboxylase tests showed that unlike most of the other enterobacteria tested, Proteus spp. and Providence cultures did not decarboxylate arginine or lysine (Table 2). To later tests toluene was added to the phthalate buffer as suggested by Møller (1954a) and under these conditions glutamic acid decarboxylase was detected in 45 of 47 Providence cultures, most of the Proteus cultures, and 7 of 8 Escherichia coli cultures (Table 3). Møller (1954c) described the decarboxylase reactions of a large number of enterobacteria which he has examined by a similar method. He increased the sensitivity of this test, and a simplified test with growing cultures (Møller, 1955), by using an acid medium to obtain the maximum amount of enzyme. We have found that some decarboxylase activity can be detected in $\boldsymbol{E}$. coli cultures grown on Lemco agar at a neutral $\mathrm{pH}$ reaction and that the glutamic decarboxylase activity of Proteus rettgeri measured manometrically, is affected less than that of $E$. coli by the original $\mathrm{pH}$ reaction of the growth medium.

Table 3. Glutamic acid decarboxylase shown by toluene-treated suspensions

$\begin{array}{lcc} & \text { No. tested } & \text { No. positive } \\ P . \text { vulgaris } & 5 & 4 \\ \text { P. mirabilis } & 9 & 8 \\ \text { P. morganii } & 7 & 1 \\ \text { P. rettgeri } & 6 & 6 \\ \text { Providence } & 47 & 45 \\ \text { E. coli } & 8 & 7\end{array}$

A washed suspension of Clostridium welchii used for the estimation of glutamic acid was tested by the micromethod and gave positive results for glutamic acid decarboxylase in 5-10 min. This mixture was then examined by paper chromatography, using $80 \%$ phenol as solvent, and $\gamma$-aminobutyric acid could be detected. A suspension of Proteus rettgeri (NCTC 7477) gave a positive glutamic acid decarboxylase reaction in $\mathbf{3 0} \mathrm{min}$. and also a similar chromatogram.

\section{DISCUSSION}

Other workers have pointed out the relation between species of the genus Proteus and the Providence group (Kauffmann, 1951; Møller, 1953, 1954a-c; Ewing et al. 1954; Singer \& Bar-Chay, 1954; Buttiaux, Osteux, Fresnoy \& Moriamez, 1954). In general, our results are in agreement, but we have added more evidence in the tendency to swarm and in the production of $\mathrm{H}_{2} \mathrm{~S}$ by Providence strains, as well as the amino acid reactions. The addition of a known sulphur source to our medium accounts for the greater sensitivity of our test for $\mathrm{H}_{2} \mathrm{~S}$ (Clarke, 1953). Only a few Providence strains split urea, but as Singer \& Bar-Chay (1954) showed, the urease-positive strains do not differ in any other respect from the urease-negative strains.

King (1953) described leucine and valine decarboxylases of Proteus vulgaris which were not present in other species of Enterobacteriaceae. We obtained positive results for almost all Proteus and Providence cultures by our microtest method. As this enzyme has a neutral $\mathrm{pH}$ optimum, and leucine is a good substrate for the deaminase, the leucine decarboxylation was probably 
obscured by its deamination. A washed suspension of $P$. rettgeri (NCTC 7477) was tested manometrically ( $\mathrm{pH} \mathrm{6.8,0.025} \mathrm{M}$-phosphate buffer, gas phase $\mathrm{N}_{2}$, with acid tip at the end of the reaction period). The suspension failed to decarboxylate leucine, but a small amount of $\mathrm{CO}_{2}$ was produced from endogenous substrate by the cells alone. Under these conditions $\boldsymbol{P}$. morganii (NCTC 3667) was shown to decarboxylate leucine, but $P$. mirabilis (NCTC 5887), which had given a doubtful reaction in Proom \& Woiwod's amine test, also failed to decarboxylate leucine.

Proteus rettgeri was separated from other Proteus spp. by Proom \& Woiwod (1951) because it gave negative results in a test for amines which were produced from valine and leucine in their medium, and did not require nicotinic acid for growth. Kauffmann (1953) went a step further and created separate genera for P. rettgeri (Rettgerella), P. morganii (Morganella) and Providence strains (Providencia), leaving Proteus with only two species, $P$. vulgaris and $\boldsymbol{P}$. mirabilis. The similarities between Proteus spp. and the Providence group suggest a natural relationship, and we do not agree with Kauffmann (1953) that separate genera are required for these different species, an opinion which he revised in 1954. We think that our work adds to the evidence linking the Providence group to the genus Proteus. The first description of a Providence culture appears to be that of Bacillus inconstans by Ornstein (1921), which was amplified by Braun \& Löwenstein (1923-4). Consequently the correct specific epithet will be inconstans, and the species should be designated as Proteus inconstans (Ornstein) nov.comb.

We are indebted to Dr W. H. Ewing for providing many of the Providence strains used, and for confirming the identity of Bacillus inconstans.

\section{REFERENCES}

Abd-el-Malek, Y. \& Gibson, T. (1948). Studies in the bacteriology of milk. II. The staphylococci and micrococci of milk. J. Dairy Res. 15, 249.

BarritT, M. M. (1936). 'The intensification of the Voges-Proskauer reaction by the addition of $\alpha$-naphthol. J. Path. Bact. 42, 441.

Batry-Smith, C. G. (1941). The detection of acetyl-methyl-carbinol in bacterial cultures. A comparative study of the methods of O'Meara and of Barritt. J. Hyg., Camb. 41, 521.

Berger, F. M. (1945). A new non-mannitol fermenting dysentery organism of the Flexner group. J. Hyg., Camb. 44, 116.

Braun, H. \& Löwenstein, P. (1923-4). Über den Bacillus inconstans. Zbl. Bakt. (1. Abt. Orig.), 91, 1.

Brooke, M. S. (1951). Biochemical investigation on certain urinary strains of Enterobacteriaceae. (1) B. cloacae, (2) Providence. Acta path. microbiol. scand. 29, 1.

Buttiaux, R., Osteux, R., Fresnoy, R. \& Moriamez, J. (1954). Les propriétés biochimiques caractéristiques du genre Proteus. Inclusion souhaitable des Providencia dans celui-ci. Ann. Inst. Pasteur, 87, 375.

Christensen, W. B. (1946). Urea decomposition as a means of differentiating Proteus and paracolon cultures from each other and from Salmonella and Shigella types. J. Bact. 52, 461.

Clarke, P. H. (1953). Hydrogen sulphide production by bacteria. J. gen. Microbiol. 8, 397. 
Clarke, P. H. \& Cowan, S. T. (1952). Biochemical methods for bacteriology. J.gen. Microbiol. 6, 187.

Ewing, W. H., Tanner, K. E. \& Dennard, D. A. (1954). The Providence group: an intermediate group of enteric bacteria. J. Infect. Dis. 94, 134.

Haynes, W. C. (1951). Pseudomonas aeruginosa-its characterization and identification. J. gen. Microbiol. 5, 939.

Henriksen, S. D. (1950). A comparison of the phenylpyruvic acid reaction and the urease test in the differentiation of Proteus from other enteric organisms. J. Bact. 60, 225.

Henriksen, S. D. \& Closs, K. (1938). The production of phenylpyruvic acid by bacteria. Acta path. microbiol. scand. 15, 101.

Holman, W. L. \& Gonzales, F. L. (1923). A test for indol based on the oxalic reaction of Gnezda. J. Bact. 8, 577 .

Kauffmann, F. (1951). Enterobacteriaceae. Copenhagen: Munksgaard.

KaUfFmann, F. (1953). On the classification and nomenclature of Enterobacteriaceae. Riv. Ist. sieroter. ital. $28,485$.

Kauffman, F. (1954). Enterobacteriaceae, 2nd ed. Copenhagen: Munksgaard.

KING, H. K. (1953). The decarboxylation of valine and leucine by washed suspensions of Proteus vulgaris. Biochem. J. 54, xi.

Koser, S. A. (1923). Utilization of the salts of organic acids by the coli-aerogenes group. J. Bact. 8, 493.

LEIfson, E. (1933). The fermentation of sodium malonate as a means of differentiating Aerobacter and Escherichia. J. Bact. 36, 329.

Møllek, V. (1953). Distribution of aminoacid decarboxylases in Enterobacteriaceae. Riass. Commun. VI Congr. int. Microbiol. 2, 611.

Møller, V. (1954a). Activity determination of aminoacid decarboxylases in Enterobacteriaceae. Acta path. microbiol. scand. 34, 102.

Møller, V. (1954b). Diagnostic use of the Braun KCN test within the Enterobacteriaceae. Acta path. microbiol. scand. 34, 115.

Møller, V. (1954c). Distribution of amino acid decarboxylases in Enterobacteriaceae. Acta path. microbiol. scand. 35, 259.

Møller, V. (1955). Simplified tests for some amino acid decarboxylases and for the arginine dihydrolase system. Acta path. microbiol. scand. 36, 158.

Ornstein, M. (1921). Zur Bakteriologie des Schmitzbacillus. Z. Hyg. InfektKr. 91, 152.

Proom, H. \& Woiwod, A. J. (1951). Amine production in the genus Proteus. J.gen. Microbiol. 5, 930.

$S_{A C H S}$ A. (1943). A report of an investigation into the characteristics of new types of non-mannitol fermenting bacilli isolated from cases of bacillary dysentery in India and Egypt. J. R. Army med. Cps, 80, 92.

Singer, J. (1953). The breakdown of aminoacids by Enterobacteriaceae. Riass. Commun. VI Congr. int. Microbiol. 1, 421.

Singer, J. \& BAR-Chay, J. (1954). Biochemical investigation of Providence strains and their relationship to the Proteus group. J. Hyg., Camb. 52, 1.

Smith, N. R., Gordon, R. E. \& Clark, F. E. (1946). Aerobic sporeforming bacteria. Misc. Publ. U.S. Dep. agric. no. 559.

Stuart, C. A., Stratum, E. van \& Rustigian, R. (1945). Further studies on urease production by Proteus and related organisms. J. Bact. 49, 437.

Stuart, C. A., Wheeler, K. M. \& McGann, V. (1946). Further studies on one anaerogenic paracolon organism type 29911. J. Bact. 52, 431.

Stuart, C. A., Wheeler, K. M., Rustigian, R. \& Zimmerman, A. (1943). Biochemical and antigenic relationships of the paracolon bacteria. J. Bact. 45, 101.

StumpF, P. K. \& Green, D. E. (1944). L-aminoacid oxidase of Proteus vulgaris. J. biol. Chem. 153, 387.

(Received 25 January 1955) 